\title{
UDZIAŁ OJCA W ZAPEWNIENIU PIERWSZEGO KONTAKTU „SKÓRA DO SKÓRY" NOWORODKOM URODZONYM DROGĄ CIĘCIA CESARSKIEGO
}

\section{THE FATHER'S CONTRIBUTION TO ENSURING THE FIRST SKIN-TO-SKIN CONTACT FOR NEWBORN BABIES BORN BY CAESAREAN SECTIONS}

\author{
Monika Salamończyk, Anna Łozińska-Czerniak, Ewa Dmoch-Gajzlerska \\ Zakład Dydaktyki Ginekologiczno-Położniczej, Wydział Nauki o Zdrowiu, Warszawski Uniwersytet Medyczny \\ DOI: https://doi.org/10.20883/ppnoz.2019.61
}

\section{STRESZCZENIE}

Wstęp. Według zaleceń WHO noworodkom urodzonym w dobrym stanie ogólnym drogą cięcia cesarskiego należy zapewnić bezpośredni kontakt z matką. W przypadku znieczulenia przewodowego powinien on trwać nieprzerwanie minimum jedną godzinę. Procedura ta jest często ograniczana ze względów organizacyjnych. Alternatywnym rozwiązaniem może być zapewnienie pierwszego kontaktu przez ojca. Stworzenie warunków do realizacji tej procedury i zachęcanie ojca do pozostania w kontakcie "skóra do skóry" z noworodkiem niesie wiele korzyści.

Cel. Celem badań była ocena zapewnienia pierwszego kontaktu „skóra do skóry” u noworodków urodzonych w dobrym stanie drogą cięcia cesarskiego oraz udział ojca w jego realizacji.

Materiał i metody. Badania przeprowadzono w 11 warszawskich placówkach położniczych. Materiał gromadzono za pomocą obserwacji bezpośredniej, którą prowadzono od stycznia 2016 r. do grudnia 2017 r. Analizie poddano 196 obserwacji bezpośrednich.

Wyniki. W większości szpitali zapewniony był pierwszy kontakt, lecz trwał on zbyt krótko i nie był realizowany według techniki „skóra do skóry”. Obecny był również ojciec, który mógłby realizować procedurę pierwszego kontaktu z noworodkiem.

Wnioski. W większości przypadków obserwowano procedurę zastosowania kontaktu "skóra do skóry" u noworodków donoszonych, w dobrym stanie ogólnym, u których możliwe było zastosowanie tej procedury. Tylko u 25,52\% przypadków zapewniono prawidłowo realizowany kontakt z matką. W większości przypadków zastosowano bezpośredni kontakt z matką, ale aż w 54,08\% kontakt realizowano w nieodpowiedniej formie. W większości przypadków - 75,51\% - w czasie wykonywania cięcia cesarskiego rodzącej towarzyszył ojciec, który mógłby brać czynny udział w zapewnieniu pierwszego, kontaktu „skóra do skóry". Wyniki badań wskazują jednoznacznie na konieczność nadzoru nad realizacją obowiązujących zaleceń dotyczących pierwszego kontaktu "skóra do skóry".

Słowa kluczowe: cesarskie cięcie, kontakt „skóra do skóry”, udział ojca, noworodek.

\section{ABSTRACT}

Introduction. Skin-to-skin contact is the positioning of a naked newborn baby covered with a warm and dry diaper or a napkin on the chest of the mother or father. During this contact, the baby is swayed in the rhythm of the parent's breathing, hears his heartbeat, and is heated.

Aim of the study. The aim of the study was to assess the father's provision of skin-to-skin contact for newborn babies born by Caesarean section.

Material and methods. Direct observation method was used in the study. The study was carried out in 11 Warsaw obstetric centers of different reference level.

Results. The time of the first skin-to-skin contact was different. Only in $11.73 \%$ of cases it was the contact immediately after birth, most often it took place after the initial assessment of the general condition - 51.53\%. During the first 2 hours after birth as much as $36.73 \%$ of the newborn child was cared for by the father.

Conclusions. In cases where the first contact was not made, as many as $80 \%$ of cases the father of the child was present in the hospital, who could be offered this procedure. The results of the study clearly indicate the need to supervise the implementation of the current recommendations for the first contact skin-to-skin, because they are not always followed.

Keywords: caesarean section, skin-to-skin contact, father's share, newborn baby.

\section{Wstęp}

Pierwszy, bezpośredni kontakt „skóra do skóry” powinien mieć miejsce tuż po urodzeniu. Jest to przywitanie się rodziców z nowonarodzonym dzieckiem. Polega na ułożeniu nagiego noworodka okrytego z zewnątrz ogrzanym i suchym materiałem (ręcznikiem, kocykiem, pieluchą lub serwetą) na klatce piersiowej matki lub ojca. Czynność ta często nazywana jest kangurowaniem. W czasie tego kontaktu dziecko jest kołysane w rytmie oddychania rodzica, słyszy jego bicie serca, przy tym jest ogrzewane. Zapewnienie tych warunków pozwala zachować ciągłość 
doznań z życia płodowego [1]. Rozróżnia się kilka wersji kontaktu "skóra do skóry" w zależności od czasu rozpoczęcia:

- bardzo wczesny - bezpośrednio po urodzeniu,

- wczesny - w pierwszej dobie po urodzeniu,

- pośredni - początek około siódmego dnia po urodzeniu,

- późny - wiele dni po urodzeniu - dotyczy wcześniaków i dzieci w złym stanie ogólnym (po fazie intensywnego leczenia) [2].

\section{Zagadnienia teoretyczne}

\section{Zalety kontaktu "skóra do skóry"}

W momencie narodzin noworodek traci komfort środowiska wewnątrzmacicznego rozpoczynając życie w środowisku zewnętrznym przez podjęcie podstawowych funkcji życiowych. Sytuacją optymalną jest łagodne przejście z macicy w ramiona matki i przebywanie w nich przez przynajmniej dwie godziny. W czasie tego kontaktu dziecko otrzymuje wiele korzyści. Do najważniejszych zalet kontaktu "skóra do skóry”, które mają korzystny wpływ na bezpośredni stan po urodzeniu i na rozwój dziecka, należą:

- redukcja stresu związanego z porodem i zapewnienie potrzeby bezpieczeństwa,

- synchronizacja ciepła u dziecka i matki (gdy temperatura dziecka obniża się, to u matki podwyższa się),

- szybszy i łatwiejszy dostęp do pokarmu matki, szybsze nabycie umiejętności ssania piersi,

- ułatwiony pasaż smółki (związany z pierwszym karmieniem),

- lepszy przyrost masy ciała,

- ułatwianie zasypiania i przejścia w głęboki sen dający wypoczynek,

- lepsza i szybsza adaptacja do nowych warunków otoczenia (przejście z wodnego środowiska do powietrznego),

- działanie przeciwbólowe,

- skracanie czasu hospitalizacji (związane z kangurowaniem u wcześniaków),

- kolonizacja błon śluzowych i skóry noworodka florą bakteryjną rodzica [1, 3-7].

Do zalet ułożenia w kontakcie "skóra do skóry" dla matki wyróżnia się:

- wyzwalanie mechanizmów hormonalnych u matki wspomagających laktację,

- zmniejszenie krwawienia po porodzie przez szybsze obkurczanie mięśnia macicy,
- redukcja stresu związanego z odbytym porodem,

- wspieranie kompetencji rodzicielskich,

- nauka odbierania i odczytywania sygnałów wysyłanych przez dziecko,

- rozwój więzi emocjonalnej między dzieckiem a matką,

- bezpośredni kontakt z dzieckiem jest ogromną nagrodą za trud porodu $[1,3]$.

Do zalet ułożenia w kontakcie „skóra do skóry” dla ojca zaliczamy:

- tworzenie głębokiej więzi z dzieckiem,

- odciążenie partnerki (matki dziecka),

- działanie kojące i uspokajające zarówno dla ojca idziecka,

- poczucie "niezbędności" u ojca $[1,4,7]$.

W przypadku braku prawidłowego przebiegu pierwszego kontaktu częściej mogą występować objawy wskazujące na zaburzenia więzi matki z dzieckiem. U kobiet częściej obserwuje się przytłoczenie pełnieniem funkcji macierzyńskiej, poczucie niekompetencji, niską satysfakcję z odbytego porodu oraz mniejszą gotowość do urodzenia kolejnego potomstwa. U niemowląt częściej pojawiają się bóle i wzdęcia brzucha (kolki), kłopoty z karmieniem oraz spokojnym snem i zasypianiem [8].

\section{Pierwszy kontakt „skóra do skóry" bezpośrednio po urodzeniu drogą cięcia cesarskiego}

Najczęściej realizowaną procedurą u kobiet związaną z porodem jest cięcie cesarskie. Obserwuje się wzrost liczby cięć cesarskich, głównie ze wskazań pozapołożniczych w szczególności na życzenie pacjentek. Cięcie cesarskie jest czynnikiem ryzyka występowania nadciśnienia płucnego oraz niewydolności oddechowej w przebiegu zespołu przejściowego przyspieszenia oddechów u noworodków donoszonych [9].

Rosnący odsetek dzieci urodzonych drogą cięcia cesarskiego wymaga zwrócenia szczególnej uwagi na stosowanie procedur, które sprzyjają przywróceniu prawidłowych mechanizmów adaptacyjnych, więzi między matką a dzieckiem oraz rozwojowi laktacji zaburzonej przez poród zabiegowy. Jedną z procedur jest zapewnienie pierwszego, bezpośredniego kontaktu matki z dzieckiem po urodzeniu [5].

Zgodnie z zaleceniami WHO kontakt "skóra do skóry" po cięciu cesarskim w znieczuleniu ogólnym (w sytuacji gdy noworodek rodzi się $w$ stanie dobrym) należy rozpocząc najwcześniej, jak to jest możliwe, najlepiej przed upływem dwóch godzin od porodu. Prawidłowo realizowany kontakt powinien spełnić następujące warunki: 
- technika jego wykonania powinna być taka sama, jak ta stosowana w przypadku dzieci urodzonych siłami natury,

- matka powinna być zdolna do nawiązania świadomego kontaktu z dzieckiem,

- należy pamiętaćo rozebraniu dziecka, mimo iż pierwszy kontakt przeprowadzany jest z opóźnieniem.

Schemat pierwszego kontaktu po cięciu cesarskim w znieczuleniu przewodowym (najczęściej zewnątrzoponowym) powinien być podobny do schematu postępowania po porodzie siłami natury. Zaleca się jego rozpoczęcie już na sali operacyjnej $\mathrm{i}$ kontynuowanie na sali pooperacyjnej, aż do zakończenia pierwszego karmienia (ale nie krócej niż jedną godzinę) [10, 11].

Noworodka należy ułożyć na klatce piersiowej matki w pozycji na boku, z główką skierowaną do piersi. Należy poprosić matkę, aby otuliła rękoma noworodka, $w$ tym czasie położna zabezpiecza dziecko przed utratą ciepła ogrzanym i suchym materiałem. Należy zachęcać matkę, aby przystawiła noworodka do piersi i kontrolować prawidłowy jego przebieg. $W$ razie rezygnacji z pierwszego kontaktu "skóra do skóry" lub jego przerwania należy wpisać informację wraz z uzasadnieniem medycznym do dokumentacji. Kwalifikacji do przebywania dziecka na klatce piersiowej matki dokonuje pielęgniarka/położna sprawująca opiekę nad noworodkiem. W sytuacji, gdy stan matki jest przeciwskazaniem do pierwszego kontaktu, noworodka powinien przejąć ojciec i realizować tę procedurę. Należy zapewnić fotel, którego oparcie ma możliwość odchylenia do pozycji półleżącej, ustawiony w bezpiecznym miejscu, zapewniającym obserwację dziecka oraz inne akcesoria dające możliwość przeprowadzenia pierwszego kontaktu "skóra do skóry" przez ojca (kocyk, poduszka, chusta stabilizująca) $[5,12,13]$.

\section{Założenia metodologiczne pracy}

\section{Cel badań}

Celem badań była ocena zapewnienia pierwszego kontaktu "skóra do skóry" u noworodków urodzonych w dobrym stanie drogą cięcia cesarskiego oraz udziału ojca w jego realizacji.

\section{Materiał i metoda}

Badania przeprowadzono w 11 warszawskich placówkach położniczych o różnym stopniu referencyjności. Materiał gromadzono za pomocą obserwacji bezpośredniej, którą prowadzono od stycznia 2016 r. do grudnia 2017 r. Przeprowadzono 500 obserwacji.
Analizie poddano 196 obserwacji dotyczących cięć cesarskich. Liczbę ich $w$ danym szpitalu wyliczono na podstawie rocznego zestawienia liczby porodów (siłami natury i cięć cesarskich) w Warszawie w 2015 r. Obserwacje prowadziły studentki studiów licencjackich na kierunku położnictwo (wcześniej przeszkolone przez autora badań) od momentu rozpoczęcia wykonywania cięcia cesarskiego do dwóch godzin od jego zakończenia. Obserwacji poddano tylko przypadki, w których noworodek urodził się w stanie dobrym - uzyskał w pierwszej i piątej minucie życia minimum 8 punktów w skali Apgar. Otrzymane wynik zapisywano w kwestionariuszu obserwacji ułożonym na potrzeby tego badania. Przeanalizowano, czy zapewniony był pierwszy, bezpośredni kontakt „skóra do skóry”, kiedy został realizowany, czy w okresie okołoporodowym był obecny ojciec dziecka lub osoba towarzysząca matce, kto sprawował opiekę nad noworodkiem po urodzeniu.

\section{Analiza wyników badań}

Badania przeprowadzono w 11 warszawskich placówkach położniczych, w których przeprowadzono 196 obserwacji bezpośrednich. W szpitalu A przeprowadzono 17,35\% obserwacji, w szpitalu B $-7,65 \%$, w szpitalu C - 6,63\%, w szpitalu D-4,08\%, w szpitalu E-3,06\%, w szpitalu F - 9,18\%, w szpitalu G - 11,73\%, w szpitalu $H-3,57 \%$, w szpitalu I - 23,24\%, w szpitalu J - 16,33\%, w szpitalu $K-8,16 \%$ obserwacji (Tabela 1).

Tabela 1. Liczba wykonanych obserwacji w poszczególnych szpitalach

\begin{tabular}{|l|c|c|c|c|} 
& N & $\begin{array}{c}\text { Skumulowany } \\
\text { N }\end{array}$ & Procent & $\begin{array}{c}\text { Skumulowany } \\
\text { procent }\end{array}$ \\
\hline Szpital A & 34 & 34 & 17,35 & 17,35 \\
\hline Szpital B & 15 & 49 & 7,65 & 25,00 \\
\hline Szpital C & 13 & 62 & 6,63 & 31,63 \\
Szpital D & 8 & 70 & 4,08 & 35,71 \\
\hline Szpital E & 6 & 76 & 3,06 & 38,78 \\
Szpital F & 18 & 94 & 9,18 & 47,96 \\
Szpital G & 23 & 117 & 11,73 & 59,69 \\
Szpital H & 7 & 124 & 3,57 & 63,27 \\
Szpital I & 24 & 148 & 12,24 & 75,51 \\
Szpital J & 32 & 180 & 16,33 & 91,84 \\
\hline Szpital K & 16 & 196 & 8,16 & 100,00
\end{tabular}

Źródło: Opracowanie własne

W 93,37\% przypadków urodziły się dojrzałe, zdrowe noworodki, 6,63\% stanowiły noworodki niedojrzałe, przedwcześnie urodzone, ale urodzone $w$ dobrym stanie ogólnym (Tabela 2). 
Tabela 2. Charakterystyka dojrzałości noworodków po urodzeniu

\begin{tabular}{|l|c|c|c|c|} 
& $\mathrm{N}$ & $\begin{array}{c}\text { Skumulowany } \\
\mathrm{N}\end{array}$ & Procent & $\begin{array}{c}\text { Skumulowany } \\
\text { procent }\end{array}$ \\
\hline $\begin{array}{l}\text { dojrzały, } \\
\text { zdrowy }\end{array}$ & 183 & 183 & 93,37 & 93,37 \\
$\begin{array}{l}\text { niedojrzały, } \\
\text { przedwcześnie } \\
\text { urodzony }\end{array}$ & 13 & 196 & 6,63 & 100,00 \\
\hline
\end{tabular}

Źródło: Opracowanie własne

W prowadzonych obserwacjach najkrócej trwająca ciąża wynosiła 35 tygodni a najdłużej 41 tygodni. Średni czas trwania ciąży to 38,78, mediana wynosiła 39 (Tabela 3).

Tabela 3. Tydzień ukończenia ciąży

\begin{tabular}{|l|c|c|c|c|c|c|c|} 
& N & Mean & SD & Median & IQR & Minimum & Maximum \\
$\begin{array}{l}\text { Tydzień } \\
\text { Ukończenia } \\
\text { ciąży }\end{array}$ & 196 & 38,78 & 1,31 & 39,00 & $\begin{array}{r}38,00- \\
40,00\end{array}$ & 35,00 & 41,00 \\
\hline
\end{tabular}

Źródło: Opracowanie własne

W większości przypadków (95,92\%) w czasie wykonywania cięcia cesarskiego zastosowano znieczulenie przewodowe. Tylko w 4,08\% operacji zastosowano znieczulenie ogólne (Tabela 4).

Tabela 4. Rodzaj zastosowanego znieczulenia u matki

\begin{tabular}{|l|c|c|c|c|} 
& $\mathrm{N}$ & $\begin{array}{c}\text { Skumulowany } \\
\mathrm{N}\end{array}$ & Procent & $\begin{array}{c}\text { Skumulowany } \\
\text { procent }\end{array}$ \\
$\begin{array}{l}\text { znieczulenie } \\
\text { przewodowe } \\
\begin{array}{l}\text { znieczulenie } \\
\text { ogólne }\end{array}\end{array}$ & 188 & 188 & 95,92 & 95,92 \\
\hline
\end{tabular}

Źródło: Opracowanie własne

W 79,59\% przypadków podjęto pierwszy kontakt matki z dzieckiem w ciągu dwóch pierwszych godzin po urodzeniu. W 20,41\% kontakt "skóra do skóry" nie został podjęty (Tabela 5).

Tabela 5. Podjęcie pierwszego kontaktu „skóra do skóry"

\begin{tabular}{|l|c|c|c|c|}
\hline & N & Skumulowany & Procent & $\begin{array}{c}\text { Skumulowany } \\
\text { procent }\end{array}$ \\
tak & 156 & 156 & 79,59 & 79,59 \\
nie & 40 & 196 & 20,41 & 100,00
\end{tabular}

Źródło: Opracowanie własne

Przeanalizowano czas podjęcia pierwszego kontaktu „skóra do skóry". Tylko w 11,73\% przypadków był to kontakt bezpośrednio po urodzeniu, najczęściej kontakt odby- wał się po wstępnej ocenie stanu ogólnego - 51,53\%, po przewiezieniu matki na salę operacyjną $16,32 \%$, po dwóch godzinach lub więcej $16,32 \%$, nie zaobserwowano kontaktu w czasie obserwacji w 4,10\% przypadków (Tabela 6).

Tabela 6. Czas podjęcia pierwszego kontaktu "skóra do skóry"

\begin{tabular}{|l|c|c|c|c|} 
& N & $\begin{array}{c}\text { Skumulowany } \\
\text { N }\end{array}$ & Procent & $\begin{array}{c}\text { Skumulowany } \\
\text { procent }\end{array}$ \\
$\begin{array}{l}\text { po wstępnej ocenie } \\
\text { stanu ogólnego } \\
\text { bezpośrednio po } \\
\text { urodzeniu }\end{array}$ & 101 & 101 & 51,53 & 51,53 \\
$\begin{array}{l}\text { po przewiezieniu } \\
\text { matki na salę } \\
\text { pooperacyjną } \\
\text { po dwóch godzinach }\end{array}$ & 32 & 156 & 16,32 & 79,58 \\
$\begin{array}{l}\text { lub więcej po } \\
\text { urodzeniu } \\
\text { nie dotyczy }\end{array}$ & 32 & 188 & 16,32 & 95,90 \\
Źródło: Opracowanie własne & 8 & 196 & 4,10 & 100,00
\end{tabular}

W badanej grupie dokonano podziału na różne metody podjęcia pierwszego kontaktu "skóra do skóry". Aż u 38,78\% badanych był to kontakt "policzek do policzka”, w $25,52 \%$ było to ułożenie na klatce piersiowej matki nagiego, okrytego bielizną noworodka, w 13,77\% przypadków był to kontakt przez ułożenie na klatce piersiowej matki ubranego dziecka, w 1,53\%przypadków noworodka pokazano matce i pozwolono pocałować w policzek, w 20,40\% nie zrealizowano pierwszego, bezpośredniego kontaktu matki z dzieckiem (Tabela 7).

Tabela 7. Metoda pierwszego kontaktu matki z dzieckiem

\begin{tabular}{|l|c|c|c|c|} 
& N & $\begin{array}{c}\text { Skumulowany } \\
\text { N }\end{array}$ & Procent & $\begin{array}{c}\text { Skumulowany } \\
\text { procent }\end{array}$ \\
$\begin{array}{l}\text { kontakt „policzek do } \\
\text { policzka” }\end{array}$ & 76 & 76 & 38,78 & 38,78 \\
$\begin{array}{l}\text { noworodek na klatce } \\
\text { piersiowej matki ubrany }\end{array}$ & 27 & 103 & 13,77 & 52,55 \\
$\begin{array}{l}\text { noworodek na klatce } \\
\text { piersiowej matki nagi, } \\
\text { okryty bielizną } \\
\text { pocałunek w policzek } \\
\text { nie dotyczy }\end{array}$ & 30 & 153 & 25,52 & 78,07 \\
\hline
\end{tabular}

Źródło: Opracowanie własne

Analizie poddano fakt przebywania osoby towarzyszącej z rodzącą w czasie wykonywania cięcia cesarskiego. W 75,51\% przypadków w czasie porodu w szpitalu był obecny ojciec dziecka, w 21,43\% nikt nie towarzyszył rodzącej, w 3,06\% nie uzyskano odpowiedzi (Tabela 8). 
Tabela 8. Przebywanie osoby towarzyszącej z rodzącą w czasie wykonywania cięcia cesarskiego

\begin{tabular}{|l|c|c|c|c|} 
& $\mathrm{N}$ & $\begin{array}{c}\text { Skumulowany } \\
\text { nikt }\end{array}$ & Procent & $\begin{array}{c}\text { Skumulowany } \\
\text { procent }\end{array}$ \\
$\begin{array}{l}\text { ojciec dziecka } \\
\begin{array}{l}\text { nie uzyskano takiej } \\
\text { informacji }\end{array}\end{array}$ & 148 & 42 & 21,43 & 21,43 \\
\hline
\end{tabular}

Źródło: Opracowanie własne

Analizie poddano obecność osoby towarzyszącej matce w grupie badanej, gdzie kontakt "skóra do skóry" nie został zrealizowany. Aż w $80,00 \%$ był obecny ojciec dziecka, 17,50\% nikt nie towarzyszył matce, w 2,5\% przypadków nie uzyskano informacji, czy ktoś towarzyszył rodzącej (Tabela 9).

Tabela 9. Obecność ojca w szpitalu z rodzącą w grupie, gdzie nie podjęto kontaktu „skóra do skóry"

\begin{tabular}{|l|c|c|c|c|} 
& N & $\begin{array}{c}\text { Skumulowany } \\
\text { N }\end{array}$ & Procent & $\begin{array}{c}\text { Skumulowany } \\
\text { procent }\end{array}$ \\
\hline nikt & 7 & 7 & 17,50 & 17,50 \\
\hline $\begin{array}{l}\text { ojciec dziecka } \\
\text { nie uzyskano takiej } \\
\text { informacji }\end{array}$ & 12 & 39 & 80,00 & 97,50 \\
\hline
\end{tabular}

292 Źródło: Opracowanie własne

W czasie dwóch pierwszych godzin po urodzeniu aż w 36,73\% opiekę nad noworodkiem sprawował ojciec dziecka. W 34,70\% położna z sali pooperacyjnej, 27,55\% położna/pielęgniarka z oddziału noworodkowego, 1,02\% położna z sali porodowej (Tabela 10).

Tabela 10. Sprawowanie opieki nad noworodkiem w czasie dwóch pierwszych godzin po urodzeniu

\begin{tabular}{|l|c|c|c|c|} 
& $\mathrm{N}$ & $\begin{array}{c}\text { Skumulowany } \\
\mathrm{N}\end{array}$ & Procent & $\begin{array}{c}\text { Skumulowany } \\
\text { procent }\end{array}$ \\
$\begin{array}{l}\text { położna z sali } \\
\text { pooperacyjnej }\end{array}$ & 68 & 68 & 34,70 & 34,70 \\
$\begin{array}{l}\text { położna/pielęgniarka } \\
\text { z oddziału } \\
\text { noworodkowego }\end{array}$ & 54 & 122 & 27,55 & 62,25 \\
$\begin{array}{l}\text { ojciec } \\
\begin{array}{l}\text { położna z sali } \\
\text { porodowej }\end{array}\end{array}$ & 72 & 194 & 36,73 & 98,98 \\
& 2 & 196 & 1,02 & 100,00
\end{tabular}

Źródło: Opracowanie własne

\section{Omówienie wyników badań}

Najważniejszą potrzebą nowonarodzonego dziecka i matki jest wzajemny kontakt łagodzący trudy porodu $[14,15]$. Cięcie cesarskie jest jedną z kilku sytuacji położniczych, które mogą wpłynąć na czas rozpoczęcia i przebieg kontaktu "skóra do skóry" i nie jest przeciwskazaniem do stosowania tej procedury. Zarówno cięcie cesarskie jak i brak wczesnego kontaktu są czynnikami niekorzystnie wpływającymi na rozpoczęcie karmienia piersią [11]. W omawianym badaniu bezpośredni kontakt matkiz dzieckiem po porodzie drogą cięcia cesarskiego był realizowany w 79,59\%. W tej grupie tylko w przypadku $25,51 \%$ był realizowany metodą bezpośredniego kontaktu nagiego noworodka na klatce piersiowej matki (taką technikę zaleca WHO). Wiadomo jest, że najlepszym sposobem ogrzania oziębionego noworodka jest kontakt z ciałem matki, ponieważ dochodzi do wzajemnej synchronizacji ciepłem (gdy temperatura dziecka spada, to u matki wzrasta) [16] Najczęstszą metodę (38,78\%) stanowił kontakt „policzek do policzka", a w 13,37\% przypadków układano na klatce piersiowej matki ubranego noworodka, w 1,53\% przypadków noworodka pokazano matce i pozwolono pocałować w policzek. Z tak realizowanego kontaktu nie korzystała w pełni ani matka, ani dziecko.

W przypadku noworodków pozbawionych możliwości nieprzerwanego kontaktu z matką (z różnych przyczyn medycznych), proponuje się, aby miały one zapewniony krótki, trwający od 1-3 minut bezpośredni kontakt po zakończeniu wykonywania czynności na stanowisku noworodkowym [11]. W omawianych badaniach taki kontakt realizowano przez technikę „policzek do policzka” i „pocałunek w policzek". Należy jednak zwrócić uwagę, że w przeprowadzonym badaniu obserwacji poddano tylko postępowanie z noworodkami w stanie ogólnym dobrym (kryterium włączenia do badania), u których istniała możliwość przeprowadzenia procedury pierwszego kontaktu.

W szpitalach coraz częściej zezwala się na uczestnictwo ojca w czasie narodzin dziecka, nawet w czasie narodzin drogą cięcia cesarskiego. $W$ omawianym badaniu ojciec był obecny w szpitalu w 71,3\% przypadków. Często po krótkim kontakcie z matką ubrany noworodek przebywał w łóżeczku poza salą operacyjną pod opieką ojca lub trafiał w jego ramiona. Najlepszym rozwiązaniem byłby bezpośredni kontakt „skóra do skóry” z ojcem w czasie trwającego nadal cięcia cesarskiego. Większość szpitali nie praktykuje tej procedury ze względów organizacyjnych. Do jej przeprowadzenia potrzebne jest miejsce, w którym stoi odpowiedni fotel umożliwiający przyjęcie przez ojca pozycji półleżącej (nie poleca się stosowania pozycji pionowej). Noworodek powinien być ułożony w pozycji, która nie ogranicza spontanicznej aktywności dziecka, umożliwiającej odpowiednie warunki oddechowe oraz inne, które stanowią o bezpieczeństwie klinicznym dziecka. Niezbędne jest rów- 
nież prowadzenie przez pielęgniarki/położne obserwacjiikontrolowanie stanu dziecka oraz asystowanie i wspieranie ojca w podjętym działaniu [4]. Należałoby zastanowić się nad korzyściami wynikającymi z bezpośredniego kontaktu i zapewnić miejsce, w którym ojciec mógłby zastąpić matkę [5].

Zapewnienie kontaktu "skóra do skóry" noworodkom urodzonym $w$ dobrym stanie ogólnym jest metodą całkowicie bezpieczną, uwzględniwszy sytuacje szczególne oraz przeciwskazania. Korzyści dla dziecka i rodziców oraz niewielkie koszty powinny być wskazówką dla personelu medycznego do powszechnego jej stosowania, w szczególności u dzieci urodzonych drogą cięcia cesarskiego. Nie należy traktować tej procedury jako przemijającej mody, lecz jako postępowanie wynikające z natury, niezakłócone przez proces medykalizacji porodu $[3,17]$.

\section{Wnioski}

1. W większości przypadków obserwowano procedurę zastosowania kontaktu "skóra do skóry" u noworodków donoszonych, w dobrym stanie ogólnym, u których możliwe było zastosowanie tej procedury. Tylko u 25,52\% przypadków zapewniono prawidłowo realizowany kontakt z matką.

2. W $79,59 \%$ zastosowano bezpośredni kontakt z matką, ale aż w 54,08\% kontakt realizowano $w$ nieodpowiedniej formie.

3. W większości przypadków - 75,51\% - w czasie wykonywania cięcia cesarskiego rodzącej towarzyszył ojciec, który mógłby brać czynny udział w zapewnieniu pierwszego kontaktu "skóra do skóry".

4. W przypadkach braku realizacji pierwszego kontaktu, aż w $80 \%$ w szpitalu obecny był ojciec dziecka, któremu można by zaproponować wykonanie tej procedury.

5. Aż $w 36,73 \%$ przypadków w czasie dwóch pierwszych godzin po porodzie opiekę nad dzieckiem sprawował ojciec dziecka.

6. Wyniki badań wskazują jednoznacznie na konieczność nadzoru nad realizacją obowiązujących zaleceń dotyczących pierwszego kontaktu "skóra do skóry", gdyż nie zawsze są one przestrzegane.

\section{Oświadczenia}

Oświadczenie dotyczące konfliktu interesów

Autorzy deklarują brak konfliktu interesów.

Źródła finansowania

Autorzy deklarują brak źródeł finansowania.
Piśmiennictwo

1. Bajek A, Marcinkowski JT, Rzempowska J, Gawłowicz K. Kangurowanie - zalecany pierwszy bezpośredni kontakt ciała noworodka z ciałem matki. Hygeia Public Health. 2014; 49(3): 417-420.

2. Anderson GC. Kangaroo Care of the premature infant. W: Nurturing the premature Infant: Developmental Interventions in the Neonatal Intensive Care Nursery (red. E. Goldson). Oxford University Press, New York 1999, 131-160.

3. Stodolak A, Fuglewicz A. Kontakt skóra do skóry i kangurowanie noworodków - chwilowa moda czy naukowo udowodniona metoda, Perinatologia, Neonatologia i Ginekologia. 2012; 5(1): s. 19-25

4. Bednarczyk $M$, Lewandowska $M$, Stobnicka-Stolarska $P_{1}$ Szozda A, Winnicka E, Zawitkowski P. Kangurowanie (KMC - Kangaroo Mother Care) jako element wspierania procesu laktacji i karmienia naturalnego oraz część kompleksowego "Systemu opieki i wczesnej stymulacji rozwojowej noworodka" (Systemu rozwojowej opieki, pielęgnacji i wspierania dojrzewania kompetencji funkcjonalnych dziecka) - rekomendowany dla Oddziałów Intensywnej Terapii Noworodka (II i III stopień referencyjności). W: Program wczesnej stymulacji laktacji dla ośrodków neonatologicznych i położniczych III poziomu referencyjności (red. E. Helwich), Standardy Medyczne, Pediatria. 2014; 11: s. 9-45.

5. Pawlus B, Kowalska I, Borszewska-Kornacka MK. Postępowanie ze zdrowym noworodkiem po cięciu cesarskim, Standardy Medyczne. Pediatria. 2012; 9: s. 275-278.

6. Ferber SG, Makhoul IR. The effect of skin-to-skin contact (kangaroo care) shortly after birth on the neurobehavioral responses of the term newborn: a randomized, controlled trial. Pediatrics. 2004; 113: 858-865.

7. Michalska E, Gebuza G, Gierszewska M, Kaźmierczak M Standard opieki nad noworodkiem z wykorzystaniem metody kangura. Standardy Medyczne. Pediatria. 2011, 8: 369-374.

8. Lessing-Pernak J. Znaczenie przebiegu porodu i wczesnego kontaktu matki z dzieckiem dla rozwoju przywiązania, Perinatologia, Neonatologia i Ginekologia. 2010; 3(4): s. 282-289.

9. Borszewska-Kornacka MK, Kufel K. Cięcie cesarskie a stan noworodka, Ginekologia Polska. 2011; 82: s. 612-617.

10. Rozporządzenie Ministra Zdrowia w sprawie standardów postępowania medycznego przy udzielaniu świadczeń zdrowotnych z zakresu opieki okołoporodowej sprawowanej nad kobietą w okresie fizjologicznej ciąży, fizjologicznego porodu, połogu oraz opieki nad noworodkiem. Dz. U. 12,1100 z dnia 4 października 2012 roku.

11. World Health Organization. Kangaroo mother care: a practical guide. Genewa, 2003.

12. Świetliński J. Neonatologia i opieka nad noworodkiem, Wydawnictwo Lekarskie PZWL, Warszawa 2016.

13. Wilińska M, Turzańska A, Składanowska M, Sonczyk W, Wysocka I, Świetliński J, Borszewska-Kornacka MK. Postępowanie ze zdrowym noworodkiem urodzonym $w$ terminie w pierwszych godzinach po urodzeniu, Standardy Medyczne, Pediatria. 2010; 7: s. 167-172.

14. Leboyer F. Narodziny bez przemocy, Mamania, Warszawa 2012.

15. Lichtenberg-Kokoszka E. Optymalne warunki narodzin. W: Dziecko aktywny uczestnik porodu, zagadnienia interdyscyplinarne (red. E. Lichtenberg-Kokoszka, E. Janiuk, J. Dzierżanowski). Oficyna Wydawnicza Impuls, Kraków 2010.

16. Bystrova K, Wassberg C, Vorontsov I, Uvnas-Moberg K. Skinto-skin contact may reduce negative consequences of "the stress of being born": a study on temperature in newborn in- 
fants, subjected to different ward routines in St. Petersburg, Acta Paediatrica, 2003; 92(3): 320-326.

17. Salamończyk M, Łozińska-Czerniak A, Dmoch-Gajzlerska E. Zapewnienie kontaktu "ciało do ciała” noworodkom urodzonym drogą cięcia cesarskiego.W: Choroby XXIw. - Analiza współczesnej sytuacji zdrowotnej (red.E. Bajek, B.A. Nowak). Wydawnictwo Naukowe TYGIEL sp. z o.o., Lublin 2017.

Zaakceptowano do edycji: 15.12 .2019 Zaakceptowano do publikacji: 15.02.2020
Adres do korespondencji:

Monika Salamończyk

ul. Żwirki i Wigury 81

02-091 Warszawa

tel. 225720705

fax. 225720705 